한반도에 발생한 위험 기상 사례에 대한 관측 민감도 분석

\author{
김세현 ${ }^{1)} \cdot$ 김현미 ${ }^{1) *} \cdot$ 김은정 ${ }^{2)} \cdot$ 신현철 ${ }^{2)}$ \\ 1)연세대학교 대기과학과, 대기예측성 및 자료동화 연구실 \\ 2)기상청 수치자료응용과
}

(접수: 2013년 1월 21일, 수정: 2013년 2월 28일, 게재확정일: 2013년 3월 14일)

\title{
Forecast Sensitivity to Observations for High-Impact Weather Events in the Korean Peninsula
}

\author{
SeHyun Kim ${ }^{1)}$, Hyun Mee Kim ${ }^{1)}$, , Eun-Jung Kim ${ }^{2)}$, and Hyun-Cheol Shin ${ }^{2)}$ \\ 1) Atmospheric Predictability and Data Assimilation Laboratory, \\ Department of Atmospheric Sciences, Yonsei University \\ ${ }^{2}$ Numerical Data Application Division, Korea Meteorological Administration
}

(Received: 21 January 2013, Revised: 28 Februry 2013, Accepted: 14 March 2013)

\begin{abstract}
Recently, the number of observations used in a data assimilation system is increasing due to the enormous amount of observations, including satellite data. However, it is not clear that all of these observations are always beneficial to the performance of the numerical weather prediction (NWP). Therefore, it is important to evaluate the effect of observations on these forecasts so that the observations can be used more usefully in NWP process. In this study, the adjoint-based Forecast Sensitivity to Observation (FSO) method with the KMA Unified Model (UM) is applied to two high-impact weather events which occurred in summer and winter in Korea in an effort to investigate the effects of observations on the forecasts of these events. The total dry energy norm is used as a response function to calculate the adjoint sensitivity. For the summer case, TEMP observations have the greatest total impact while BOGUS shows the greatest impact per observation for all of the 24-, 36-, and 48-hour forecasts. For the winter case, aircraft, ATOVS, and ESA have the greatest total impact for the 24-, 36-, and 48-hour forecasts respectively, while ESA has the greatest impact per observation. Most of the observation effects are horizontally located upwind or in the vicinity of the Korean peninsula. The fraction of beneficial observations is less than $50 \%$, which is less than the results in previous studies. As an additional experiment, the total moist energy norm is used as a response function to measure the sensitivity of 24-hour forecast error to observations. The characteristics of the observation impact with the moist energy response function are generally similar to those with the dry energy response function. However, the ATOVS observations were found to be sensitive to the response function, showing a positive (a negative) effect on the forecast when using the dry (moist) norm for the summer case. For the winter case, the dry and moist energy norm experiments show very similar results because the adjoint of KMA UM does not calculate the specific humidity of ice properly such that the dry and moist energy norms are very similar except for the humidity in air that is very low in winter.
\end{abstract}

Key words: Forecast sensitivity to observation, KMA unified model, data assimilation, adjointbased method, observation impact

*Corresponding Author: Hyun Mee Kim, Department of Atmospheric Sciences, Yonsei University, 50 Yonsei-ro, Seodaemun-gu, Seoul, 120749, Republic of Korea.

Phone : +82-2-2123-5683, Fax :+82-2-365-5163

E-mail : khm@yonsei.ac.kr 


\section{1. 서 론}

수치 예보 모델 시스템 안에서 자료 동화는 배경장 과 관측 자료들을 각각의 오차 공분산을 통해 적절히 조합해줌으로써 좀 더 정확한 초기 조건을 생성하여 예보의 정확도를 높이기 위한 과정으로 사용된다. 최 근 들어 위성 자료들의 사용으로 자료 동화 과정에는 방대한 양의 관측 자료가 사용되고 있으며, 관측 종 들의 개수도 점점 증가하는 추세이다. 사용되는 관측 자료가 증가할수록 자료 동화 과정도 점점 더 복잡해 지고, 사용되는 관측 종과 자료가 많다고 해서 모든 관측이 예보에 매번 긍정적인 영향을 주는지는 확실 하지 않기 때문에, 자료 동화 과정에 사용되는 관측 자료들이 수치 예보에 미치는 영향을 평가하고 분석 하는 것은 매우 중요하다.

관측 자료들이 수치 예보에 미치는 영향을 평가하 는 방법으로는 전통적으로 Observation System Experiments (OSEs)가 있다. OSEs는 자료 동화 과정에서 관 측 종들을 제거하거나 더함으로써 특정 관측 종의 영 향을 판단할 수 있는 방법이다 (Kelly et al., 2007). 평가하기를 원하는 관측 종에 대해서 실험 시간이나 지역을 설정하여 제어할 수 있음에도 불구하고, 관측 종의 구성을 다르게 할 때마다 실험을 반복해야 하기 때문에 비용과 시간이 많이 드는 단점이 있지만, 공 식적인 현업 센터에서 예보 모델과 관측 자료간의 영 향을 알아보기 위해 사용하기도 한다 (Bouttier and Kelly 2001; English et al., 2004; Lord et al., 2004). 이러한 OSEs의 단점을 보완한 방법으로는 Baker and Daley (2000)에서 제시한 adjoint 방법을 이용해서 예 보에 대한 관측의 영향을 평가하는 방법이 있다. Adjoint 방법을 이용한 관측 영향 평가는 관측 민감도를 정량 적으로 계산하여 평가하는 것으로, adjoint 방법을 이 용해서 한 번의 모델 수행만으로도 자료 동화에 사용 된 모든 관측 종의 예보에 대한 영향을 평가할 수 있 어 OSEs와 비교하여 계산 비용 및 시간이 적게 든다. 이 방법을 단 기간의 예보 오차에 적용한 연구로는 Langland and Baker (2004), Zhu and Gelaro (2008), Gelaro et al. (2010) 등이 있다. Langland and Baker (2004)는 미국 Naval Research Laboratory (NRL) 자료 동화 시스템의 adjoint 모듈을 이용해서 단 기간의 예 보 오차에 대한 관측의 영향을 평가하였고, $\mathrm{Zhu}$ and Gelaro (2008)는 자료 동화 과정에서 좀 더 정확한 관 측 민감도를 얻을 수 있도록 Gridpoint Statistical Interpolation (GSI)의 adjoint 코드를 개발하였다. Gelaro et al. (2010)은 세 가지 예보 시스템 (NRL의 Navy Operational Global Atmospheric Prediction System, Global Modeling and Assimilation Office 의 Goddard Earth Observing System-5, 그리고 Environment Canada
의 Global Deterministic Prediction System)의 관측 민 감도 결과를 비교하였다. 또한 Gelaro and Zhu (2009) 와 Cardinali (2009)는 단 기간의 예보 오차에 대해서 adjoint 방법을 이용한 실험과 OSEs 실험의 결과가 비 슷함을 보였다. 전구 모델이 아닌 Weather Research and Forecasting (WRF) 지역 모델의 ajoint를 이용하 여 북서태평양에서 예보에 미치는 관측의 영향을 계 산하고 분석한 연구로는 Jung et al. (2012)이 있다. Adjoint 방법을 이용해서 예보에 미치는 관측의 영향 을 평가하는 것을 관측 자료에 대한 예측 민감도 (Forecast Sensitivity to Observation: FSO)라 통칭한다. 본 연구에서는 현재 기상청에서 현업으로 사용 중 인 영국 기상청 (UKMO: United Kingdom Meteorological Office)의 통합 모델 (Unified Model: UM)과 FSO 평가 시스템을 한반도에 발생한 여름철과 겨울 철 위험 기상 사례들에 적용하여 관측 자료가 예보에 미치는 영향을 분석해 보려 한다. 2장에서는 $\mathrm{UM}$ 의 $\mathrm{FSO}$ 계산 방법을 설명하였고, 3장에서는 사례에 적 용한 결과를 나타내었다. 마지막으로 요약 및 결론은 4장에 제시하였다.

\section{2. 방 법}

\section{1. 통합모델의 FSO}

통합모델에서 예보에 미치는 관측 자료의 영향을 계산하는 방법은 Joo et al. (2012)에 자세히 기술되어 있다. 관측 민감도는 adjoint 방법을 이용하기 때문에 adjoint 즉 수반 모델에 사용되는 반응함수를 적절히 설정해주어야 한다. 수반 모델에 관한 자세한 설명은 Errico (1997)에 나와 있다. 예보 오차에 관한 관측의 영향을 계산하기 위하여 다음과 같이 반응 함수를 설 정하였다.

$$
\begin{aligned}
& J=\left(\delta \mathbf{w}^{f}\right)^{\mathrm{T}} \mathbf{C}\left(\delta \mathbf{w}^{f}\right) \\
& =\iiint\left[\frac{1}{2} \rho\left(u^{\prime 2}+{v^{\prime}}^{2}+{w^{\prime}}^{2}\right)+\frac{p}{2 \kappa \theta_{\text {ref }}^{2}} \theta^{\prime 2}+\frac{1}{2 \gamma p} p^{\prime 2}\right] d x d y d \eta
\end{aligned}
$$

여기서 $\mathrm{T}$ 는 전치 행렬 (Transpose matrix)을, $\delta w^{f}$ 는 마 지막 시점에서의 모델 예보장과 분석장 간의 차이를 나타내며, C는 Clayton (2004)에 언급된 체적 평균된 건조 에너지 놈 (norm)이다. $u^{\prime}, v^{\prime}, w^{\prime}, \theta^{\prime}, p^{\prime}$ 은 각각 3 차원 바람장, 온위, 기압섭동의 예보 오차를 나타내 며, $\kappa=R / C_{p} \cong 0.286, \gamma=C_{p} / C_{v} \cong 1.4$, 그리고 $\theta_{r e f}=$ $300 \mathrm{~K}$ 를 의미한다. 따라서 반응 함수는 건조 에너지 단위의 예보 오차가 되며, 이는 지역 투영 행렬 (Buizza, 1994)을 이용하여 관심 지역을 지정하여 계산할 수 있 다. 지역 투영 행렬은 관심 지역 안의 에너지는 유지 
하고 관심 지역 밖의 에너지는 0 으로 만들어 주는 역 할을 한다. 통합모델 시스템에서는 반응 함수를 다음 과 같은 식으로 변환하여 사용한다.

$\delta J=\left(\delta \mathbf{w}_{t}^{f a}\right)^{\mathrm{T}} \mathbf{C}\left(\delta \mathbf{w}_{t}^{f a}\right)-\left(\delta \mathbf{w}_{t}^{f b}\right)^{\mathrm{T}} \mathbf{C}\left(\delta \mathbf{w}_{t}^{f b}\right)=\left(\delta \mathbf{w}_{t}\right)^{\mathrm{T}}\left(\frac{\delta J}{\delta \mathbf{w}_{t}}\right)$

$\delta \mathbf{w}_{t}^{f a}$ 는 $\mathrm{t}$ 시간까지 자료동화 효과가 포함된 분석장으 로부터 적분된 예보의 오차 $\left(\delta \mathbf{w}_{t}^{f a}=\mathbf{x}_{t}^{f a}-\mathbf{x}_{t}^{a}\right), \delta \mathbf{w}_{t}^{f b}$ 는 자료동화 효과가 포함되지 않은 배경장으로부터 적 분된 예보의 오차 $\left(\delta \mathbf{w}_{t}^{f b}=\mathbf{x}_{t}^{f b}-\mathbf{x}_{t}^{a}\right)$ 이고, $\delta \mathbf{w}_{t}=$ $\left(\delta \mathbf{w}_{t}^{f a}-\delta \mathbf{w}_{t}^{f b}\right)$ 로 관측 자료의 동화로 인한 예보장의 변화를 나타내며, $\left(\delta J / \delta \mathbf{w}_{t}\right)=\mathrm{C}\left(\delta \mathbf{w}_{t}^{f a}+\delta \mathbf{w}_{t}^{f b}\right)$ 는 예측 민감도 벡터를 의미한다. 여기서 $\mathbf{x}_{t}^{f b}, \mathbf{w}_{t}^{f a}$ 그리고 $\mathbf{x}_{t}^{a}$ 은 모두 $\mathrm{t}$ 시간에서의 예보 벡터이며, 각각 $\mathrm{t}_{\mathrm{b}}-3 \mathrm{~h}$, $\mathrm{t}_{\mathrm{a}}$ - $3 \mathrm{~h}$ 그리고 $\mathrm{t}_{\mathrm{t}}-3 \mathrm{~h}$ 시간부터의 모델 예보 값을 의 미한다 (Fig. 1). 통합모델 시스템에서는 3시간의 분 석 증분을 이용하여 분석장을 생성하므로 $\mathbf{x}_{t}^{a}$ 를 참값 으로 간주한다. 일반적으로 자료동화 효과가 포함된 $\delta \mathbf{w}_{t}^{f a}$ 가 $\delta \mathbf{w}_{t}^{f b}$ 보다 작은 값을 가져 $\delta \mathbf{w}_{t}$ 가 음의 값이 되므로, 식 (2)에 의해 $\delta J$ 가 음의 값을 갖는 것이 관 측 자료의 동화가 예보에 긍정적인 영향을 준 것, 즉 예보 오차를 감소시키는 것으로 분석한다.

관측에 의한 반응 함수의 변화를 관측에 관한 식으 로 표현하기 위하여 다음과 같은 관계식을 이용한다.

$$
\delta \mathbf{w}_{t} \approx \mathbf{M K} \delta \mathbf{y}
$$

여기서 $\mathbf{M}$ 은 선형화된 예보 모델을, $\mathbf{K}$ 는 Kalman gain 행렬로써 통합모델 시스템 안의 4차원 변분 자료 동 화 알고리즘 (Four Dimensional Variational data assimilation: 4D-Var)에서 계산되며, $\delta \mathbf{y}$ 는 관측의 innovation (관측과 배경장의 차이)을 나타낸다. 식 (3)

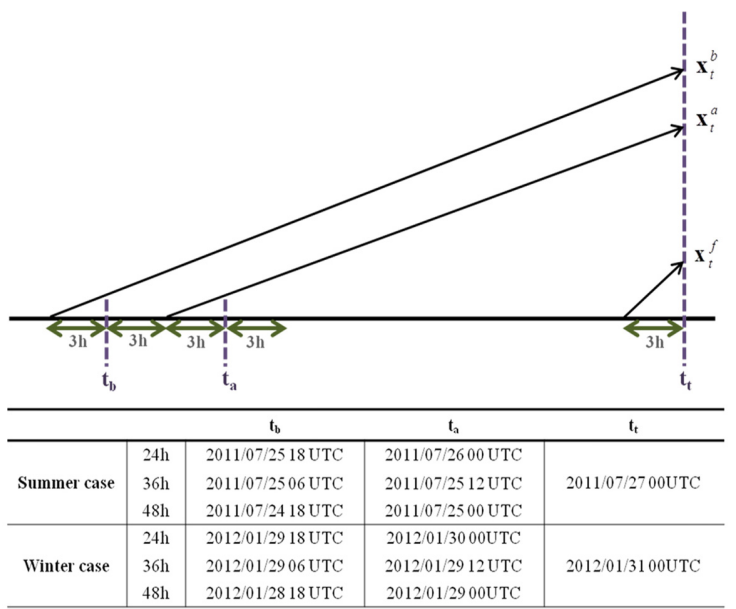

Fig. 1. Schematic of experimental framework.
을 이용하여, 식 (2)를 다시 표현하면 다음과 같다.

$$
\delta J \approx(\mathbf{M K} \delta \mathbf{y})^{\mathrm{T}}\left(\frac{\delta J}{\delta \mathbf{w}_{t}}\right)=\delta \mathbf{y}^{\mathrm{T}} \mathbf{K}^{\mathrm{T}} \mathbf{M}^{\mathrm{T}} \mathbf{C}\left(\delta \mathbf{w}_{t}^{f a}+\delta \mathbf{w}_{t}^{f b}\right)
$$

여기서 $\mathbf{K}^{\mathrm{T}}$ 와 $\mathbf{M}^{\mathrm{T}}$ 는 각각 Kalman gain 행렬과 선형화 된 예보 모델의 수반 모델이다. (4)식의 양 변을 관측 innovation으로 나누어주면 아래 식 (5)와 같이 표현된다.

$$
\left(\frac{\delta J}{\delta \mathbf{y}}\right) \approx \mathbf{K}^{\mathrm{T}} \mathbf{M}^{\mathrm{T}} \mathbf{C}\left(\delta \mathbf{w}_{t}^{f a}+\delta \mathbf{w}_{t}^{f b}\right)
$$

즉, 관측 innovation에 대한 건조 에너지 단위의 예보 오차의 변화를 알 수 있게 되며, 총 관측 영향인 $\delta J$ 는 관측의 민감도 $(\delta J / \delta \mathbf{y})$ 와 관측의 innovation $(\delta \mathbf{y})$ 의 곱으로 나타낼 수 있음을 알 수 있다. 또한 $\delta \mathbf{y}$ 가 벡 터의 형태이기에, 예를 들어 관측 자료가 $\mathrm{n}$ 개의 관측 종으로 구성되어 있다면, 다음과 같은 형태로 나타낼 수 있다.

$$
\delta J_{n} \approx \delta y_{n}\left(\frac{\delta J}{\delta \mathbf{y}}\right)_{n}
$$

따라서 $\mathrm{FSO}$ 를 이용하면 앞서 말한 바와 같이 한 번 의 수반 적분을 통해 자료동화에 이용된 모든 관측 종들이 예보에 미치는 영향을 계산할 수 있다.

\section{2. 실험 설계 및 사례}

\subsection{1. 실험 설계}

이 실험에 사용한 시스템은 현재 기상청에서 사용 하고 있는 통합모델 $\mathrm{Vn}$ 7.7과 통합모델 변분 자료 동 화 시스템 $\mathrm{Vn}$ 27.2이다. 모델의 초기 조건은 $\mathrm{KMA}$ $4 \mathrm{DVAR}$ 시스템에서 생산된 분석장을 사용하였으며, 수치 실험의 영역은 전구이다. 수평적으로는 중위도 지역에서 $25 \mathrm{~km}$ 의 해상도를 갖는 $1024 \times 769$ 개의 격 자를 사용하였으며, 연직으로는 71개의 eta-height hybrid 층을 사용하였다. 선형 모델의 수반모델에서 사용되 는 기본류 값들은 $\mathrm{UM}$ 비선형 모델로부터 제공이 되 며, 비선형 적분 과정에서 사용된 물리 모수화 과정 들은 Edwards-Slingo radiation (Edwards and Slingo, 1996), mixed phase precipitation (Wilson and Ballard, 1999), Met Office surface exchange scheme (Essery et al., 2001), non-local boundary layer (Lock et al., 2000), new GWD scheme (Webster et al., 2003), mass flux convection scheme (Kershaw and Gregory, 1997; Gregory et al., 1997)이다. 이 과정들 중에 선형 및 수 반 모델 적분에서는 mass flux convection scheme과 mixed phase precipitation을 사용하지 않고, non-local boundary layer 대신에 fixed boundary layer를 사용하 며, 이와 같은 물리 과정 설정은 $\mathrm{Kim}$ et al. (2011)과 동일하다. 앞서 2.1.장에서 설명한 통합모델의 $\mathrm{FSO}$ 를 
아래 2.2.2.절에서 기술하는 위험 기상 사례들에 적용 하기 위하여 다음과 같은 실험 설계를 하였다.

모든 실험은 $\mathrm{t}_{\mathrm{a}}$ 에서의 관측 자료들이 $\mathrm{t}_{\mathrm{t}}$ 시간의 예보 에 주는 영향을 평가하는 것으로, $\mathrm{t}_{\mathrm{t}}-\mathrm{t}_{\mathrm{a}}$ 를 각각 24,36 그리고 48 시간으로 설정하여 적분 시간대별 관측 자 료의 영향을 평가해보았다. 즉, $\mathrm{t}_{\mathrm{t}}$ 시간으로부터 24,36 그리고 48 시간 전의 관측 자료가 $\mathrm{t}_{\mathrm{t}}$ 시간의 예보에 미 치는 영향을 계산하였다. 관측 자료는 전구 자료를 사 용하였으며, 모델 영역도 전구로 설정하였다. 이 연구 에서는 한반도에 발생한 위험 기상 사례들의 예보에 미치는 관측 자료의 영향을 살펴보는 것이므로, 반응 함수 영역은 한반도 부근 $\left(\right.$ 위도 $33^{\circ} \sim 41^{\circ} \mathrm{N}$, 경도 $123^{\circ} \sim$ $130^{\circ} \mathrm{E}$ )으로 제한하여 계산하였고 (Figs. $2 \mathrm{~d}$ and $3 \mathrm{~d}$ ), $\mathrm{t}_{\mathrm{t}}$
시간은 여름과 겨울 사례 각각 2011년 7월 27일 0000 UTC와 2012년 1월 31일 $0000 \mathrm{UTC}$ 로 사례의 강도가 가장 강하였던 시간 부근에서 관측 자료가 많은 시간 대로 설정하였다.

추가적인 실험으로는 24시간 예보 오차에 대한 관 측 자료의 영향을 총 건조 에너지 뿐만 아니라 총 습 윤 에너지로도 계산하여 그 차이를 살펴보았다. 습윤 에너지 놈에 대한 반응 함수는 다음과 같이 계산된다.

$$
\begin{aligned}
J_{\text {moist }}= & \iiint\left[\frac{1}{2} \rho\left({u^{\prime}}^{2}+{v^{\prime}}^{2}+{w^{\prime}}^{2}\right)+\frac{p}{2 \kappa \theta_{\text {ref }}^{2}} \theta^{\prime^{2}}+\frac{1}{2 \gamma p} p^{\prime 2}\right. \\
& \left.+\frac{\rho L^{2}}{2 C_{p} T} q^{\prime 2}\right] d x d y d \eta
\end{aligned}
$$
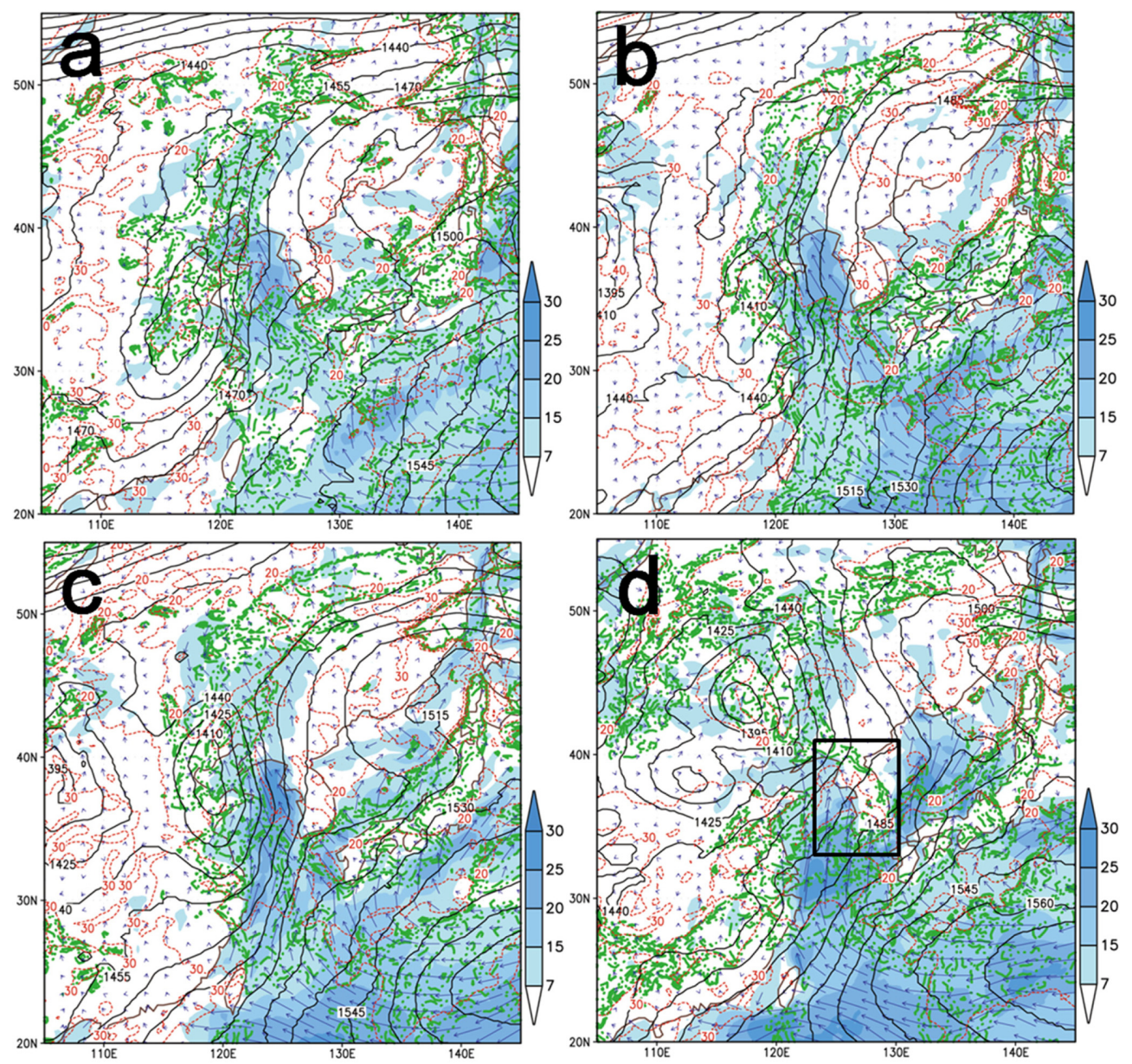

Fig. 2. $850 \mathrm{hPa}$ geopotential height (black solid, contour interval of $15 \mathrm{gpm}$ ), $1000 \mathrm{hPa}$ temperature (red dotted, contour interval of $5 \mathrm{~K}$ ), $1000 \mathrm{hPa}$ relative humidity with regard to water (green dotted, larger than $85 \%$ ), $1000 \mathrm{hPa}$ wind speed (shaded, $\mathrm{m} \mathrm{s}^{-2}$ ) and wind direction (arrow) at (a) 0000 UTC 25, (b) 1200 UTC 25, (c) 0000 UTC 26, and (d) 0000 UTC 27 July 2011, from 3-hour forecast field of KMA Unified Model. The box in (d) denotes a geographic region for defining a response function for adjoint sensitivity calculation. 
여기서 $q^{\prime}$ 는 비습 섭동의 예보 오차이며, $\mathrm{C}_{\mathrm{p}}$ 와 $\mathrm{L}$ 은 각 각 정압 비열과 단위 질량당 응결 잠열이다.

\subsection{2. 사례}

예보에 미치는 관측의 영향을 평가하기 위하여 한 반도에 발생한 위험 기상 사례를 여름과 겨울에서 각 각 한 사례씩 선정하였다. 먼저 여름철 사례의 경우 2011년 7월 25일 저녁의 소나기를 시작으로, 7월 28 일까지 내린 집중호우 사례이다. 이 사례의 경우 북 태평양 고기압의 가장자리를 따라 유입된 따뜻하고 습윤한 공기와 대기 중하층의 건조한 공기 사이에서 강화된 대기 불안정이 강한 비 구름대를 발달시켰으 며, 우리나라 북동쪽에 위치한 저지 고기압으로 인해
비구름대가 정체되어 한반도의 중부 지방과 남해안을 중심으로 평균적으로 많은 양의 비가 내렸다. 특히 대 도심인 서울 남부 지역에 6 12시간 정도 지속돼 관 측 이래 기록적인 비가 내린 사례이다. Fig. 2 를 보면 모든 시간대에서 한반도의 서쪽에는 강한 바람이, 남 서쪽 및 남쪽으로는 높은 습도가 나타나고 있음을 확 인할 수 있다. 기류의 흐름 또한 시간이 갈수록 한반 도의 남서쪽에서 남서풍의 방향이라 많은 양의 비가 내릴 수 있는 조건인 것으로 분석된다.

겨울철 사례는 2012년 1월 31일에 발생한 대설 사 례이다. 2012년 1월 중순까지 양의 값을 보이던 북극 진동이 음의 값으로 변하여, 찬 대륙고기압이 확장되 어 한반도의 중부지방과 경북 내륙 지방에 한파 특보
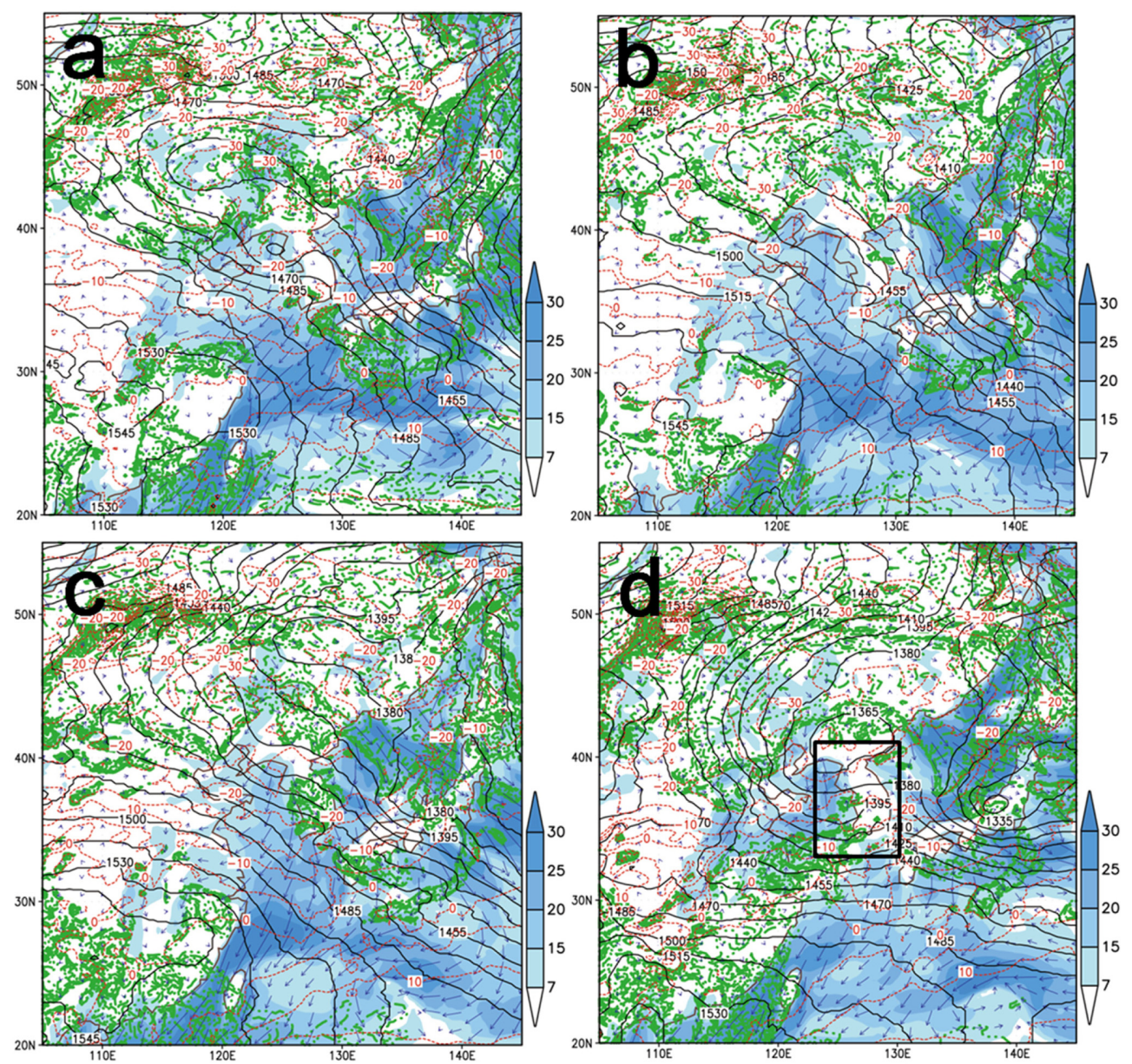

Fig. 3. $850 \mathrm{hPa}$ geopotential height (black solid, contour interval of $15 \mathrm{gpm}$ ), $1000 \mathrm{hPa}$ temperature (red dotted, contour interval of $5 \mathrm{~K}$ ), $1000 \mathrm{hPa}$ relative humidity with regard to ice (green dotted, larger than $80 \%$ ), $1000 \mathrm{hPa}$ wind speed (shaded, $\mathrm{m} \mathrm{s}^{-2}$ ) and wind direction (arrow) at (a) 0000 UTC 29, (b) 1200 UTC 29, (c) 0000 UTC 30, and (d) 0000 UTC 31 January 2012, from 3 hours forecast field of KMA Unified Model. The box in (d) denotes a geographic region for defining a response function for adjoint sensitivity calculation. 
가 발효 중이었다. 폭설의 직접적인 원인으로는 발해 만에서 발달하여 이동해온 저기압이 한반도의 중부지 방을 관통하여 서울을 비롯한 중부 및 경북 지방에 많은 양의 눈을 내렸으며, 폭설 이후 온도가 크게 떨 어져 55년만의 한파가 발생한 사례이다. Fig. 3을 보 면, 모든 시간대에 한반도 부근에서 강한 북풍 계열 의 바람이 불고 있는 것을 볼 수 있어 찬 공기의 이 류가 있었음을 확인할 수 있다. 또한 2012년 1월 30 일 $0000 \mathrm{UTC}$ 에는 한반도 전체에 얼음에 대한 상대 습도가 굉장히 높게 나왔으며, 31일 $0000 \mathrm{UTC}$ 에는
주로 중부와 남해지방에 상대습도가 높았고, 한반도 의 서쪽으로 저기압성 기류가 흐르고 있어, 앞서 말 한 저기압이 한반도로 향하고 있음을 확인할 수 있다.

\section{3. 결 과}

\section{1. 여름 사례}

3.1.1. 관측 효과와 관측 민감도

여름 사례에 대해 예보에 미치는 각 관측 종의 영 향 (이하 관측 효과와 혼용)은 Fig. 4에 나타내었다.

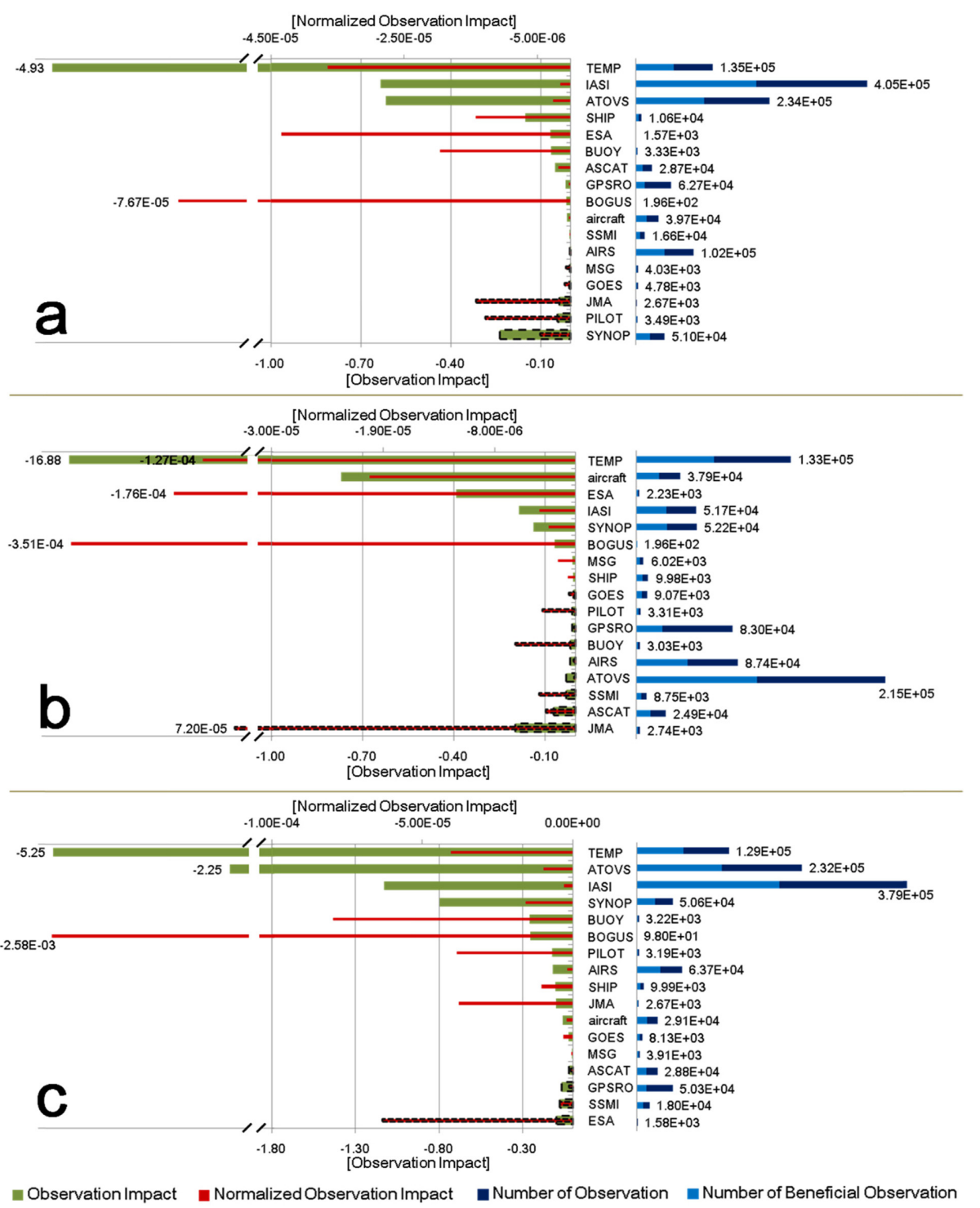

Fig. 4. Observation impact, normalized observation impact, number of observation, and number of beneficial observation of each observation type for (a) 24, (b) 36, and (c) 48-hour forecast error with dry total energy norm, for summer case. The positive value of observation impact for each observation type is denoted as dashed line.

한국기상학회 대기 제23권 2호(2013) 
각 시간의 예보 오차에 대하여 총 관측 효과는 24시 간은 약 $-6.24 \mathrm{~J} \mathrm{~kg}^{-1}, 36$ 시간은 약 $-18.06 \mathrm{~J} \mathrm{~kg}^{-1}$ 그 리고 48 시간은 약 $-10.20 \mathrm{~J} \mathrm{~kg}^{-1}$ 으로, 36시간에서 관 측 자료가 예보 오차를 감소시키는 율이 가장 높은 것으로 나타났다. 이는 식 (6)에 제시된 관측 효과를 결정하는 두 요인 (관측 민감도와 관측 innovation) 중, 관측 민감도 (특히 TEMP 관측에 대한 관측 민감도) 의 크기가 36 시간 예보에 대해 다른 시간들에 비해 컸기 때문이다. 24 시간 예보 보다 36 시간 예보에서 관 측 민감도의 크기가 큰 것은 후진 적분 기간이 길어 질수록 수반 민감도의 크기가 커지는 것과 관련이 있 으며, 36시간 예보 보다 48시간 예보에 대해서 관측 민감도의 크기가 줄어드는 것은 적분 시간이 길어짐 에 따라 관측이 예보에 미치는 영향이 줄어드는 것과 관련이 있다. 따라서 관측 민감도는 후진 적분이 진 행됨에 따라 특정 시점까지 증가하다가 그 시점을 지 나면 관측이 예보에 미치는 영향이 줄어듦에 따라 감 소하는 것으로 보이며, 이 사례에 대해서는 그 시점 이 36시간이기에 관측이 예보에 미치는 효과가 36시 간 예보에 대해 가장 크게 나타난 것으로 분석된다.

예보 오차를 감소시키는데 있어 효과가 좋은 관측 종은 24시간은 TEMP, IASI, ATOV 순으로 나타났으 며, 36시간은 TEMP, aircraft, ESA 순, 48시간은 TEMP, ATOVS, IASI 순으로 나타나 TEMP 관측이 모든 적 분 시간대의 예보 오차에서 가장 좋은 효과를 나타냈 다. 이와 같은 관측 효과는 Fig. 4의 오른쪽을 보면 알 수 있듯이, 관측 종의 개수와는 상관이 없는 것을 알 수 있다. 특정 관측의 관측 효과를 그 관측의 총 개수로 나눈 정규화된 관측 효과의 경우, BOGUS 관 측이 모든 적분 시간 대의 예보 오차에서 가장 좋은 효과를 나타냈다. 또한 관측 종별 총 관측 개수와 예 보 오차를 감소시키는 관측 개수의 비를 살펴보면, 여 름 사례 실험에서는 평균적으로 약 $48.76 \%$ 정도임을 확인할 수 있었다. 즉 전체 관측 수의 $48.76 \%$ 만이 예 보 오차를 감소시킴을 알 수 있다.

관측 효과의 수평적인 분포를 보기 위해 연직적으 로 적분하여 한 층으로 나타낸 수평장을 그려보았다 (Fig. 5). 관측 효과는 대부분 한반도의 풍상측 동아시 아 지역에 분포하는 모습을 보이는데, 이는 한반도의 풍상측 지역의 관측이 이 여름 위험 기상 사례의 예 보 오차를 감소시키는 데 중요한 역할을 함을 의미한 다. 또한 이 결과는 한반도 부근을 반응 함수로 설정 하여 수반 민감도를 계산한 결과와도 유사하다 $(\mathrm{Kim}$ et al., 2008; Jung and Kim, 2009). 예보 시간이 길어 질수록 더 서쪽으로 분포지역이 이동하며, 영역이 점 차 한반도 주변으로 확대 되는 것을 확인할 수 있다. 또한 관측 효과가 음의 값을 갖는 (즉 예보 오차가 감 소하는) 영역이 한반도의 풍상측에 위치함을 볼 수 있
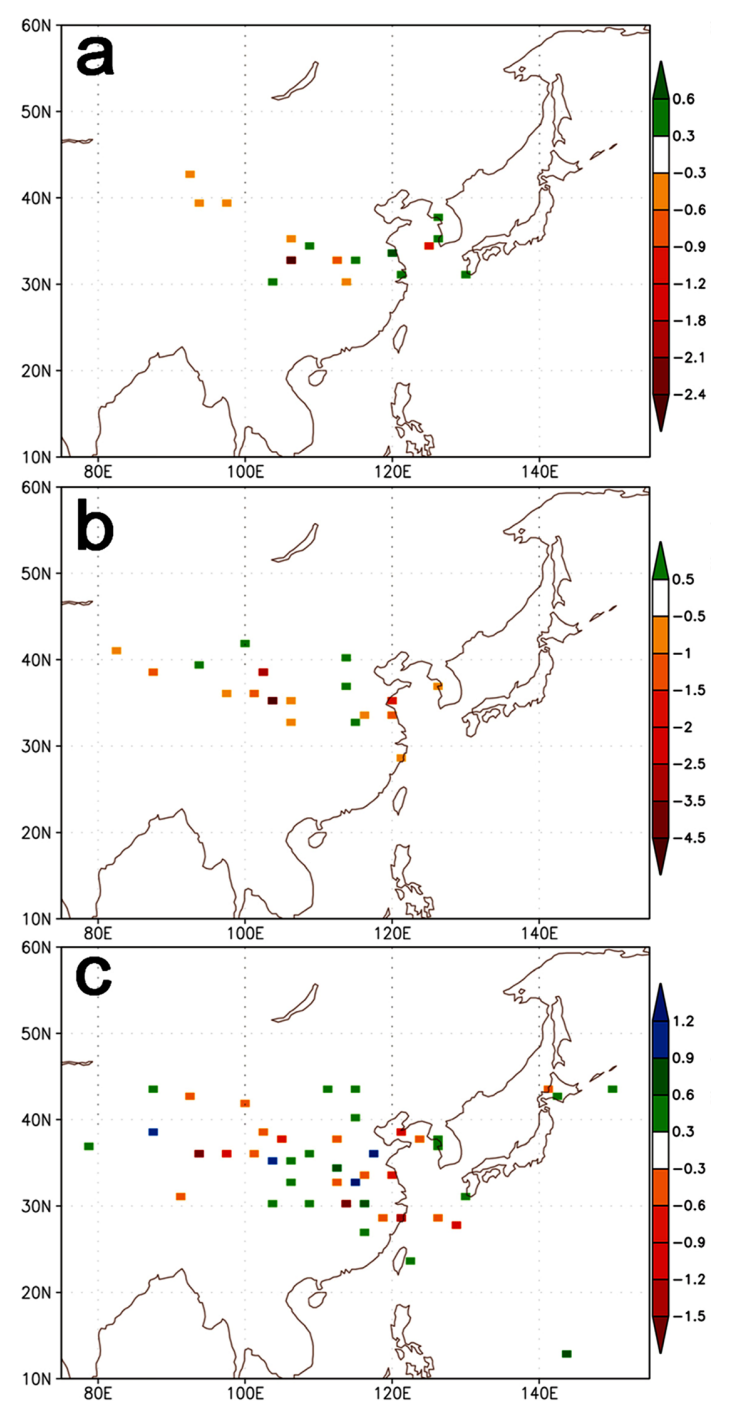

Fig. 5. Vertically integrated horizontal distribution of total observation impact $\left(\mathrm{J} \mathrm{kg}^{-1}\right)$ for (a) 24, (b) 36, and (c) 48hour forecast error with dry total energy norm, for summer case.

다. 관측 효과가 양의 값을 갖는 (즉 예보 오차가 증 가하는) 영역 또한 대부분 한반도의 풍상측에 위치하 고 있으나, 24시간이나 48시간 예보에 대해서는 한반 도 북쪽이나 남쪽 또는 풍하측에 위치하기도 한다.

관측 종별 관측 효과의 수평 분포를 살펴 보기 위 하여, 모든 시간에서 총 예보오차 감소율이 컸던 TEMP 와 정규화된 관측 효과가 컸던 BOGUS를 식 (6)을 이 용하여 관측효과, 관측 민감도, 관측 innovation으로 나누어 살펴보았다. TEMP의 관측 효과를 살펴 본 결 과 24시간 예보 오차에 대한 총 관측 효과 (Fig. 5a) 

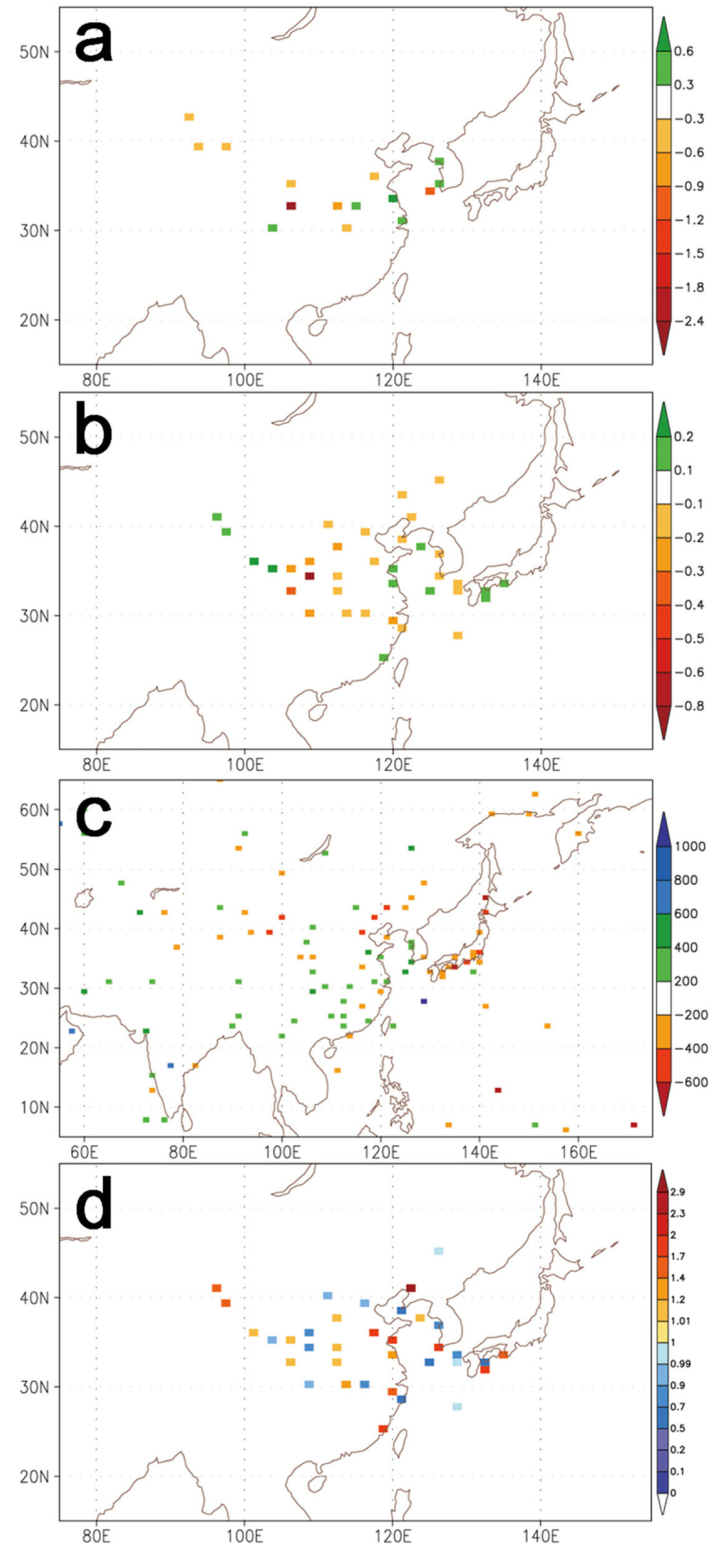

Fig. 6. Vertically integrated horizontal distribution of (a) TEMP observation impact, (b) TEMP observation sensitivity, (c) TEMP observation innovation, and (d) number of observations with positive observation impact/ number of observations with negative observation impact in sensitive regions in (b) for 24-hour forecast error with dry total energy norm, for summer case.

와 비슷한 분포를 보이는 것을 확인할 수 있었고 (Fig. 6a), 이는 TEMP의 효과가 다른 관측 종들의 효과에 비해 많이 크기 때문으로 분석된다. TEMP의 관측 민
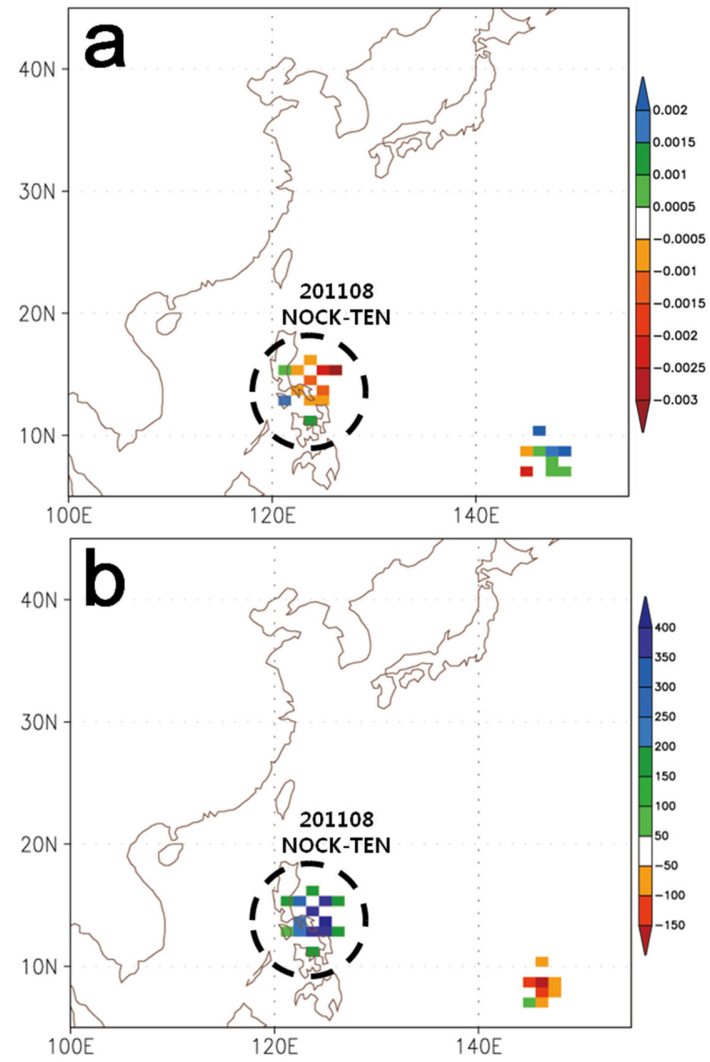

Fig. 7. Vertically integrated horizontal distribution of (a) observation sensitivity and (b) observation innovation of BOGUS observation for 24-hour forecast error with dry total energy norm, for summer case.

감도의 경우 대부분의 민감도는 음의 값을 가지며, 한 반도의 서쪽에 주로 분포하고 있음을 볼 수 있다 (Fig. 6b). TEMP 관측의 innovation의 경우 대체로 양의 값 을 갖는 것을 확인할 수 있었고, 그 위치는 대체로 대 륙 지역에 위치함을 확인할 수 있었다 (Fig. 6c). TEMP 의 관측 효과는 각 관측 지역에서의 TEMP의 관측 민 감도와 관측 innovation의 곱을 통해서 얻어지며, 전 구 관측 자료의 사용으로 넓은 지역에 나타나는 관측 innovation 보다는 반응 함수 영역과 관련하여 국지적 으로 나타나는 관측 민감도의 위치와 더 밀접한 관련 이 있는 것을 확인할 수 있다 (Figs. 6b and 6c). TEMP 관측의 효과가 컸던 이유를 살펴보기 위하여, TEMP 의 관측 민감 지역에서 음의 관측 효과 (긍정적 효과) 를 보이는 TEMP 관측의 수와 양의 관측 효과 (부정 적 효과)를 보이는 TEMP 관측의 수의 비를 구하였 다 (Fig. 6d). 비율이 1보다 큰 값일 경우 긍정적인 효 과를 주는 관측의 개수가 더 많은 것을 의미한다. 
$\mathrm{TEMP}$ 의 경우 민감 지역에서 대체로 긍정적인 효과 를 주는 관측의 개수가 더 크고 넓게 나타나는 것을 확인할 수 있어 예보 오차 감소에 긍정적인 영향을 미치는 것으로 분석할 수 있다.

실험에서 사용한 여름 사례에는 2011년 7월 26일 0000 UTC에 발생한 2011년 8호 태풍 NOCK-TEN이
발생하여 그 위치에 BOGUS 자료가 위치하는 것을 확인할 수 있었다. BOGUS의 경우는 예보 시간에 계 산된 태풍의 부근에 관측 민감도와 innovation이 집중 되어 나타났다. 그로 인하여 관측의 개수가 적어도 큰 관측 영향을 가지게 되어 정규화된 관측 영향이 크게 나타난 것으로 분석 된다 (Fig. 7). TEMP 관측과 마

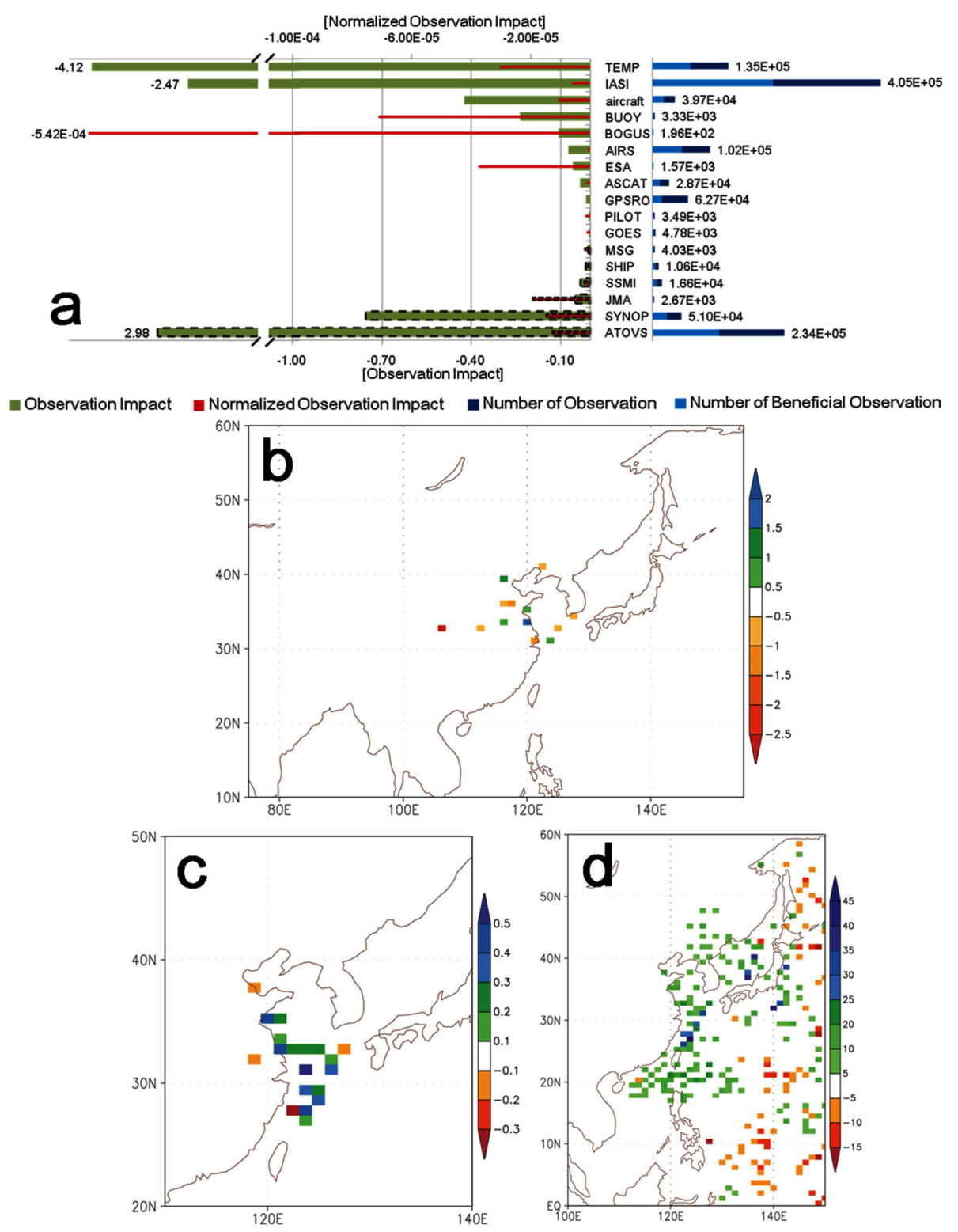

Fig. 8. (a) Observation impact, normalized observation impact, number of observation, and number of beneficial observation of each observation type for 24-hour forecast error with moist total energy norm, for summer case. The positive value of observation impact for each observation type is denoted as dashed line (ATOVS $+2.98 \mathrm{~J} \mathrm{~kg}^{-1}$ ). Vertically integrated horizontal distribution of (b) total observation impact $\left(\mathrm{J} \mathrm{kg}^{-1}\right)$, (c) ATOVS observation impact, and (d) observation innovation of ATOVS for 24-hour forecast error with moist total energy norm, for summer case. 
찬가지로 BOGUS 관측도 관측민감도와 관측 innovation 의 부호가 달라 예보 오차 감소에 긍정적 영향을 미 치는 것으로 볼 수 있다.

3.1.2. 습윤 에너지 반응 함수에 대한 관측 효과 반응 함수에 습윤 효과를 고려했을 때의 관측 민감 도 변화를 살펴보기 위하여, 24시간 예보 오차 실험 에 대해서만 반응 함수를 총 습윤 에너지 단위의 예 보 오차로 설정하여 실험을 수행해 보았다 (Fig. 8).
총 관측 효과는 약 $-3.67 \mathrm{~J} \mathrm{~kg}^{-1}$ 이며, TEMP, IASI 순 으로 좋은 관측 효과를 나타냈고, 정규화된 관측 효 과도 BOGUS 관측 종이 가장 크게 나타나는 등 건조 에너지 단위 예보 오차로 수행한 실험 (Fig. 4a)과 유 사한 모습을 보이는 것을 볼 수 있다 (Fig. 8a). 하지 만 ATOVS 관측의 경우 총 습윤 에너지 단위의 예보 오차에 대해선 가장 부정적인 효과를 보여 반응함수 의 성질에 굉장히 민감하게 반응함을 확인할 수 있다. 총 관측 효과의 수평 분포는 건조 에너지와 습윤 에
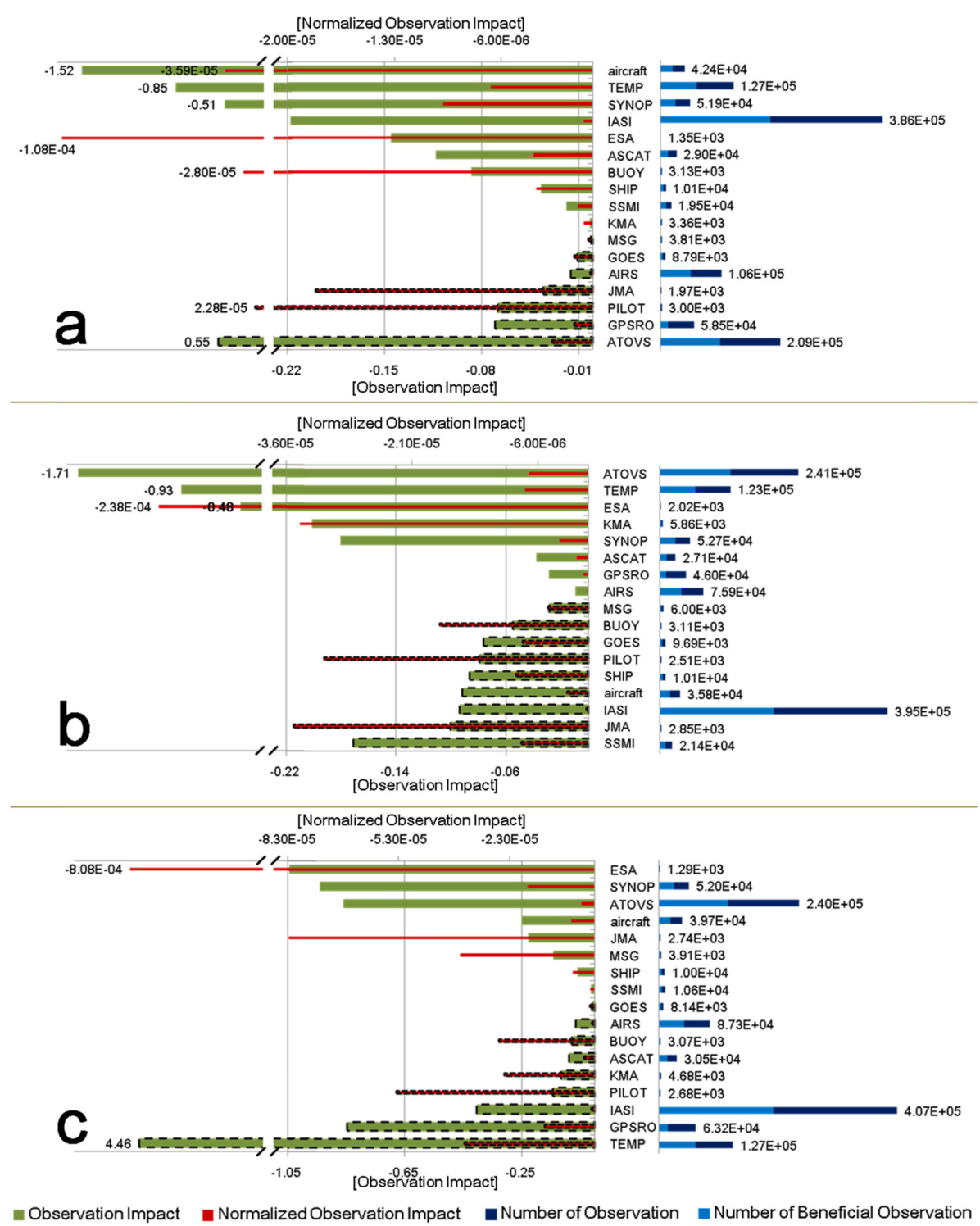

Fig. 9. Observation impact, normalized observation impact, number of observation, and number of beneficial observation of each observation type for (a) 24 , (b) 36 , and (c) 48 -hour forecast error with dry total energy norm, for winter case. The positive value of observation impact for each observation type is denoted as dashed line.

한국기상학회 대기 제23권 2호 (2013) 
너지의 두 반응 함수에 대해 다른 모습을 나타냈다. 건조 에너지 단위 예보 오차로 수행한 실험에서 주로 중국의 내륙에 분포하던 총 관측 효과는 (Fig. 5a), 습 윤 에너지 단위 예보 오차로 수행 했을 때는 주로 산 둥반도 지역을 중심으로 분포하였으며 (Fig. $8 \mathrm{~b}$ ), 이 는 실험 시간의 기상장에서 습도가 높은 곳이다 (Fig. 2c). 반응 함수에 따라 가장 민감한 모습을 나타낸 $\mathrm{ATOVS}$ 의 관측 효과를 좀 더 자세히 살펴보기 위해 수평장으로 나타내 본 결과, 한반도의 남서쪽에서 부 정적인 관측 효과를 보였다 (Fig. $8 \mathrm{c}$ ). 이 지역은 앞서 사례 설명에서도 살펴보았듯이, 강한 바람과 함께 수 증기가 많이 집중되었던 지역으로, 한반도의 집중호 우 또는 호우 시에 수증기의 유입과 관련이 많은 지 역이다. 실험에 사용된 ATOVS 자료는 크게 3가지 센 서 (AMSU-A,B 와 HIRS)로 나뉘어져 있다. 이 센서 들의 관측 효과를 각각 따로 살펴 본 결과, AMSU-A 는 약 $2.96 \mathrm{~J} \mathrm{~kg}^{-1}$, $\mathrm{AMSU}-\mathrm{B}$ 는 약 $0.15 \mathrm{~J} \mathrm{~kg}^{-1}$ 그리고 $\mathrm{HIRS}$ 는 $-0.13 \mathrm{~J} \mathrm{~kg}^{-1}$ 으로 $\mathrm{AMSU}-\mathrm{A}$ 의 효과가 가장 좋 지 않음을 알 수 있었다. AMSU-A는 온도를 관측하 는 센서로, 주어진 분석 시간 동안 한반도의 남서쪽 에서 북동쪽을 지나며 (Fig. 8d), 여름 사례의 24시간 예보 오차에 대해 한반도 남서쪽에서 부정적인 영향 을 주는 관측을 한 것으로 분석된다. 선행 연구들에 서는 AMSU-A 센서가 예보 오차를 줄이는데 기여도 가 높은 것으로 나타나 이 연구의 결과와 다른데, 그 이유는 선행 연구들이 반응 함수를 전구로 설정한 반 면 이 연구는 반응 함수를 한반도 부근으로 설정하여 한반도에 영향을 준 특정 시점의 예보 오차에 대한 AMSU-A의 효과를 봤기 때문이다. 즉 전구 예보 오 차를 감소시키는 데는 $\mathrm{AMSU}-\mathrm{A}$ 가 효과적이지만 한 반도 부근의 특정 사례에 대해서는 꼭 그렇지는 않다 는 것을 의미한다.

\section{2. 겨울 사례}

\subsection{1. 관측 효과와 관측 민감도}

겨울 사례에 대한 관측 자료들의 관측 효과의 결과 는 Fig. 9에 나타내었다. 각 시간의 예보 오차에 대하 여 총 관측 효과는 24 시간은 약 $-2.75 \mathrm{~J} \mathrm{~kg}^{-1}, 36$ 시간 은 약 $-2.80 \mathrm{~J} \mathrm{~kg}^{-1}$ 그리고 48 시간은 약 $2.68 \mathrm{~J} \mathrm{~kg}^{-1}$ 으로 36 시간에서의 관측 자료의 영향이 가장 좋은 것 으로 나타났으며, 48시간에서는 오히려 관측으로 인 해 예보 오차가 조금 증가하는 것으로 나타났다. 하 지만 예보 시간 별로 총 관측 효과가 유사해서, 겨울 사례의 경우 여름 사례에 비해 예보 시간에 따른 총 관측 효과의 차이는 크지 않은 것으로 보인다. 각 예 보 오차 별로 효과가 좋은 관측 종은 24시간은 aircraft, TEMP, SYNOP 순으로 나타났으며, 36시간은 ATOVS, TEMP, ESA, 48시간은 ESA, SYNOP, ATOVS로 나타
났다. 여름 사례에서 좋은 효과를 보였던 TEMP와 IASI 관측은 24시간 예보 오차에 대해서는 마찬가지 로 좋은 효과를 보였으나, 36,48 시간 예보 오차에 대 해서는 좋지 않은 효과를 보였다. 특정 관측의 관측 효과를 그 관측의 총 개수로 나눈 정규화된 관측 효 과의 경우, $\mathrm{ESA}$ 관측이 모든 적분 시간 대의 예보 오 차에서 가장 좋은 효과를 나타냈다. 또한 관측 종별 총 관측 개수와 예보 오차를 감소시키는 관측 개수의 비를 살펴보면, 겨울 사례 실험에서는 평균적으로 약 $48.68 \%$ 정도임을 확인할 수 있었다. 즉 전체 관측 수 의 $48.68 \%$ 만이 예보 오차의 감소에 관여하고 있음을 알 수 있었고 이는 여름 사례의 경우와 비슷한 수치 로, 이 논문에서 연구된 사례들에 대해서는 전체 관 측 개수에 대해 예보 오차를 감소시키는 관측 개수의 비율 차이가 여름과 겨울에 대해 거의 없음을 보여준다.
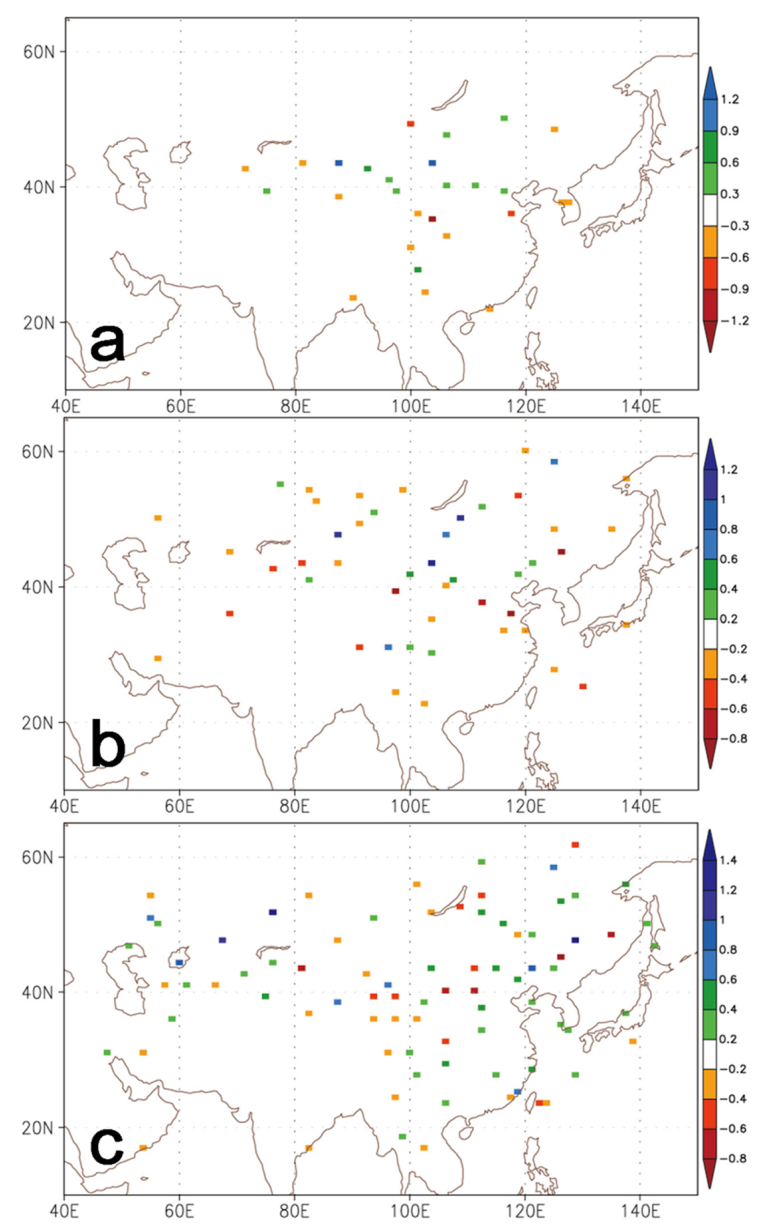

Fig. 10. Vertically integrated horizontal distribution of total observation impact $\left(\mathrm{J} \mathrm{kg}^{-1}\right)$ for (a) 24, (b) 36, and (c) 48-hour forecast error with dry total energy norm, for winter case. 
관측 효과의 수평적인 모습을 보기 위해 연직적으 로 적분하여 한 층의 수평장으로 나타내었다 (Fig. 10). 여름 사례와 마찬가지로 한반도의 서쪽에서 많은 값 이 나타났으며, 예보 시간이 길어 질수록 점점 더 넓
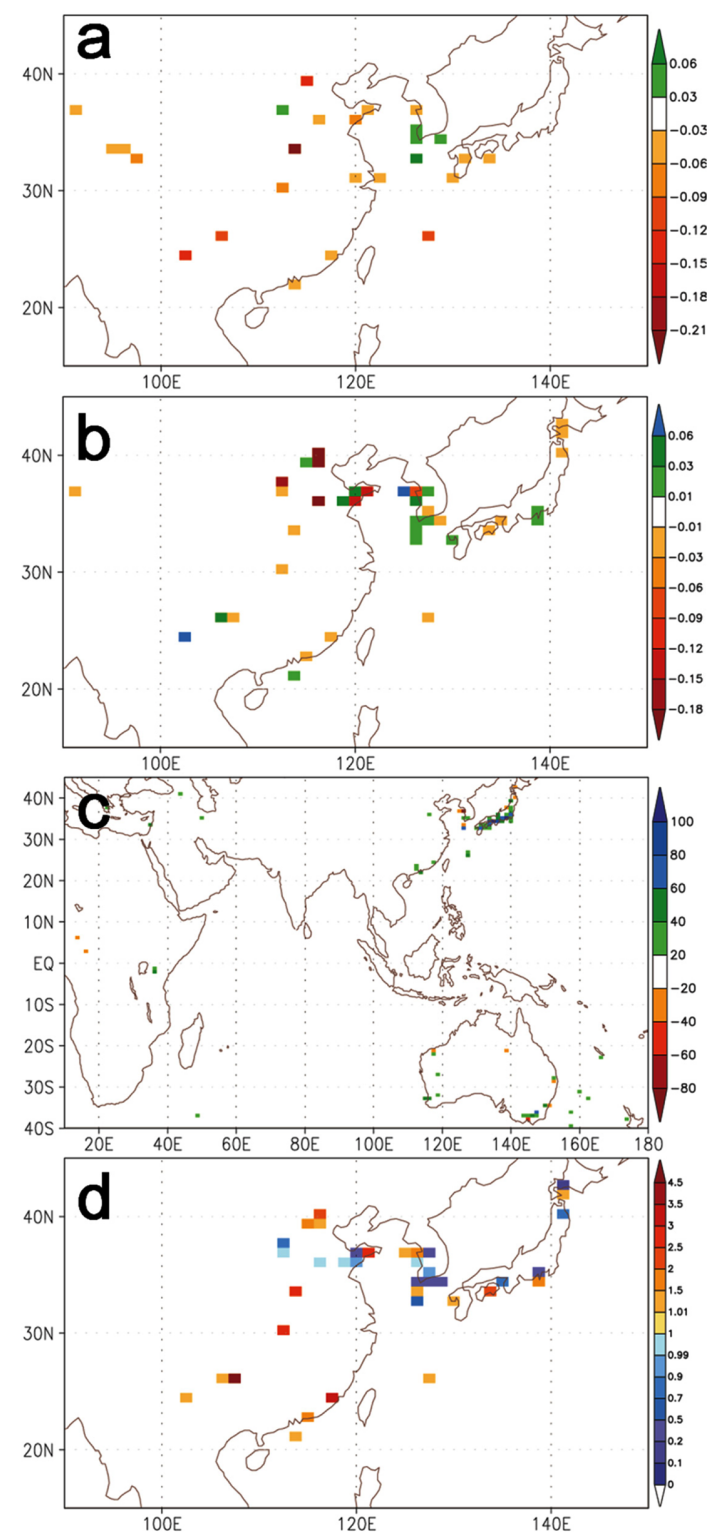

Fig. 11. Vertically integrated horizontal distribution of (a) aircraft observation impact, (b) aircraft observation sensitivity, (c) aircraft observation innovation, and (d) number of observations with positive observation impact/ number of observations with negative observation impact in sensitive regions in (b) for 24-hour forecast error with dry total energy norm, for winter case.
게 분포하며 한반도의 남과 북 및 풍하측으로도 퍼져 있는 모습을 보였다. 총 관측 영향이 양의 값을 가진 48시간 예보 오차 실험은 다른 시간들에 비해 한반도 주변에서 양의 값을 더 많이 갖는 것을 확인할 수 있 다. 특히 한반도의 북쪽과 중국의 북서부 지역에서 부 정적인 관측 효과가 크게 나타나는 것을 볼 수 있다 (Fig. 10c). 총 관측 효과가 가장 큰 관측 종과 정규화 된 관측 효과가 가장 큰 관측 종들의 수평장도 살펴 보았다.

대표적으로 Fig. 11에 24시간 예보 오차에 대하여 가장 좋은 관측 효과를 보이는 aircraft 관측의 관측 효과, 관측 민감도, innovation과 관측 민감 지역에서 긍정적 관측 효과와 부정적 관측 효과를 보이는 관측 개수의 비율을 나타내었다. 관측 효과는 주로 한반도

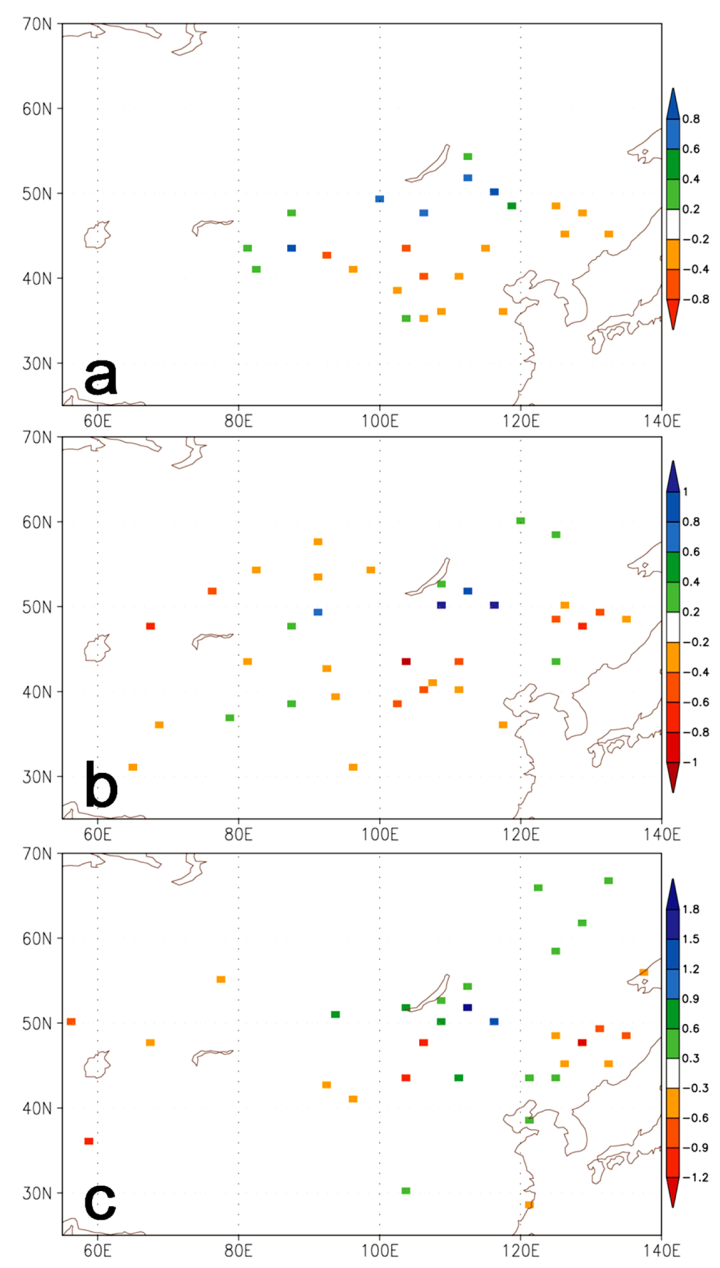

Fig. 12. Vertically integrated horizontal distribution of TEMP observation impact $\left(\mathrm{J} \mathrm{kg}^{-1}\right)$ for (a) 24, (b) 36, and (c) 48 -hour forecast error with dry total energy norm, for winter case. 
부근과 중국에 (Fig. 11a), 관측 민감도는 산둥반도 부 근과 한반도에 (Fig. 11b), innovation은 주로 한반도와 일본에 위치하는 것을 확인할 수 있다 (Fig. 11c). 여 름 사례의 TEMP와 마찬가지로 관측 효과는 관측 innovation보다는 관측 민감 지역과 비슷한 모습을 보 였다. 관측 민감 지역에 대해 긍정적 관측 효과와 부 정적 관측 효과를 보이는 관측 개수의 비율을 구해본 결과, 여름 사례의 TEMP 관측의 비해 긍정적인 효과 의 크기가 부정적인 효과에 비해 크지 않은 모습을 보여 aircraft의 총 관측 효과가 많이 크지 않았던 것 으로 분석된다. 모든 시간의 예보 오차에 대하여 가 장 큰 정규화된 관측 효과를 가진 ESA (METEOSAT7 위성 관측) 관측은 그 효과가 한반도와는 상당히 거 리가 있는 우즈베키스탄 쪽에서 나타났으며, 관측 민 감도와 innovation 모두 그 지역에 집중되어 있어 여 름 사례의 BOGUS와 마찬가지로 정규화된 관측 영향 이 크게 나타난 것으로 분석 된다 (not shown).

여름 사례에서와 마찬가지로 24,36 시간 예보 오차 에 대해선 좋은 효과를 보였지만, 48시간 예보 오차
에 대해선 좋지 않은 효과를 보인 TEMP 관측의 효 과도 수평장으로 살펴보았다 (Fig. 12). 중국의 동쪽 에서 좋은 효과를 보였던 TEMP 관측의 효과는 48시 간 실험에서는 거의 나타나지 않았지만, 한반도의 북 서쪽에 나타나는 부정적인 효과는 모든 실험 시간에 대해 존재하는 모습을 보였다. 계속해서 부정적인 효 과를 갖는 지역은 Fig. 3에서 볼 수 있듯이 온도의 경 도가 상대적으로 크게 나타나는 지역으로, 그 지역에 서의 TEMP의 관측이 모든 실험 시간에 대하여 좋지 않은 효과를 보인 것으로 분석된다.

\subsection{2. 습윤 에너지 반응 함수에 대한 관측 효과}

24 시간 예보 오차 실험에 대해서만 반응 함수를 총 습윤 에너지 단위의 예보 오차로 설정하여 실험을 수 행해 보았다 (Fig. 13). 총 습윤 에너지 단위의 24시 간 예보 오차에 대한 관측 효과는 약 $-2.83 \mathrm{~J} \mathrm{~kg}^{-1}$ 으 로 총 건조 에너지 단위로 계산했을 때 (약 $-2.75 \mathrm{~J}$ $\mathrm{kg}^{-1}$ )와 유사한 값을 나타내었으며, 효과가 좋은 관측 종은 aircraft, TEMP, SYNOP 순이었고, 정규화된 관
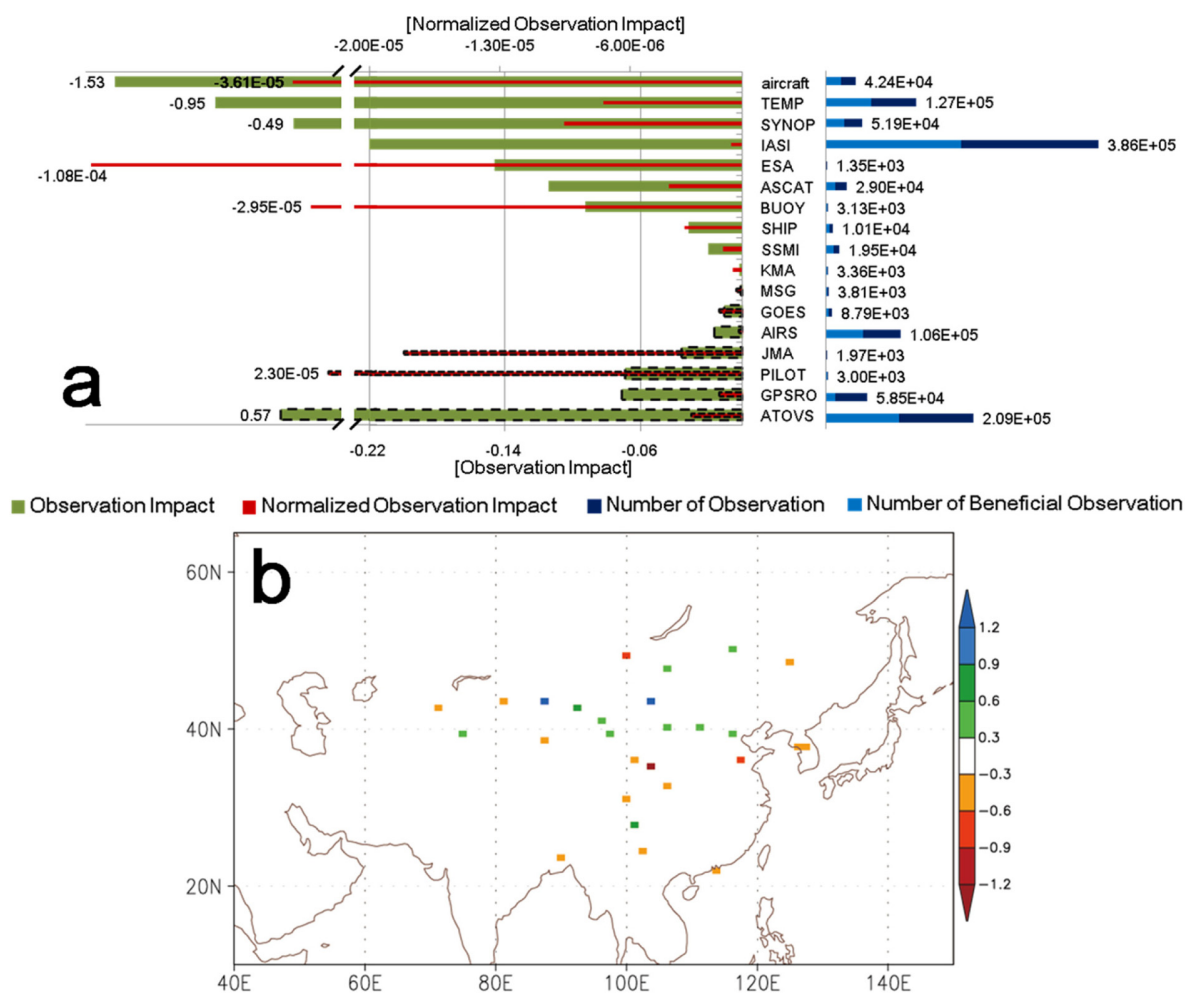

Fig. 13. (a) Observation impact, normalized observation impact, number of observation, and number of beneficial observation of each observation type for 24-hour forecast error with moist total energy norm, for winter case. The positive value of observation impact for each observation type is denoted as dashed line (ATOVS $+0.57 \mathrm{~J} \mathrm{~kg}^{-1}$ ). Vertically integrated horizontal distribution of (b) total observation impact $\left(\mathrm{J} \mathrm{kg}^{-1}\right)$ for 24-hour forecast error with moist total energy norm, for winter case. 
측 효과가 가장 좋은 관측은 $\mathrm{ESA}$ 로 나타나 전체적인 관측 영향 특성이 건조 에너지 반응 함수에 대한 것 과 비슷함을 확인할 수 있었다. 총 관측 효과의 수평 분포 또한 건조 에너지와 습윤 에너지 반응 함수를 이용한 두 실험 간의 차이가 거의 없었다. 이는 24시 간 예보 오차뿐만 아니라 추가적으로 36 시간, 48시간 의 예보 오차에 대해서 수행해본 결과에서도 사용한 반응 함수의 성질에 관계 없이 거의 유사하게 나오는 것을 확인할 수 있었고, 이러한 현상의 원인은 반응 함수에 있는 것으로 분석되었다. 앞서 수식 (7)에서 본 바와 같이, 총 습윤 에너지 단위의 예보 오차의 계 산에는 총 건조 에너지 단위의 계산과는 달리 건조 공기 안에 들어있는 습윤 공기 (수증기)의 비를 의미 하는 비습 $\mathrm{q}$ 에 대한 항이 추가적으로 들어간다. 통합 모델의 수반 모델 적분 과정에서 $\mathrm{q}$ 변수는 얼음 상태 에 대해서는 계산되지 않아, 겨울 사례에 대해서는 습 윤 에너지 반응 함수가 건조 에너지 반응 함수와 마 찬가지로 계산되게 된다. 이로 인해 겨울 사례에서는 여름 사례와는 달리 반응 함수의 성질에 따른 차이가 거의 없는 것으로 나타났으며, 약간의 차이는 대기 중 에 존재하는 매우 적은 양의 수증기에 의한 것으로 분석된다.

\section{4. 요약 및 결론}

본 연구에서는 통합 모델의 관측 민감도 도구를 이 용하여 한반도에 발생한 두 가지 위험 기상 사례의 예보 오차에 대하여, 전구 관측 종들의 영향을 평가 및 분석하였다. 관측 효과 평가를 위하여 여름철 집 중 호우 사례와 겨울철 대설 사례를 하나씩 선택하였다.

여름 사례의 경우 2011년 7월 25일 28일 발생한 집 중호우 사례로, 많은 양의 강수량과 피해가 발생했던 사례이고, 겨울 사례의 경우 2012년 1월 31일에 발생 한 대설 사례이다. 두 사례에 대해 24시간, 36시간 그 리고 48시간의 예보 오차를 이용하여 시간대 별 관측 효과를 계산해 본 결과, 겨울 사례의 48 시간 예보 오 차에 대한 실험을 제외하고 모든 실험이 총 관측 영 향이 음의 값을 보여, 관측 자료를 동화함으로써 예 보 오차가 감소함을 확인할 수 있었다. 관측 종별로 예보 오차 감소에 가장 큰 영향을 준 관측 종 여름 사례는 모든 시간대에서 TEMP 관측이었으며, 겨울 사례는 시간대 별로 각각 다르게 나타나 24시간 예보 에 대해서는 aircraft, 36시간 예보에 대해서는 ATOVS, 48시간 예보에 대해서는 ESA 관측이 예보 오차를 많 이 감소시켰다.

관측의 효과를 그 관측의 총 개수로 나눈 정규화된 관측 효과의 경우, 여름 사례는 BOGUS 관측이, 겨울 사례는 ESA가 모든 시간의 예보 오차에 대해 예보
오차 감소 효과가 가장 좋은 것으로 나타났다. 두 사 례에 대하여 관측 효과의 수평 분포를 확인해 본 결 과, 대부분의 관측 효과가 한반도의 풍상측인 서쪽에 위치하고 있었으며, 예보 시간이 길어 질수록 점차 한 반도 주변으로 확대 되는 것을 확인할 수 있었다. 또 한, 긍정적인 효과를 가진 관측 종들의 관측 효과를 수평적으로 살펴보았을 때, 관측 효과는 관측의 innovation 보다는 관측 민감도의 위치와 관련이 있는 것으로 나타났으며, 관측 민감 지역에서 긍정적인 효 과를 보이는 관측이 많을수록 관측 효과가 크게 나타 나는 것을 확인할 수 있었다. 또한 두 사례 모두 36 시간에서 관측 자료가 예보 오차를 감소시키는 율이 가장 높은 것으로 나타났는데, 이는 관측 민감도의 크 기가 36시간 예보에 대해 다른 시간들에 비해 컸기 때문이다. 관측 민감도는 후진 적분이 진행됨에 따라 수반 민감도의 크기가 커지는 것과 비례하여 증가하 다가 특정 시점을 지나면 관측이 예보에 미치는 영향 이 줄어듦에 따라 감소하는 것으로 보이며, 이 사례 에 대해서는 그 시점이 36시간이기에 관측이 예보에 미치는 효과가 36 시간 예보에 대해 가장 크게 나타난 것으로 분석된다.

두 사례의 24 시간 예보 오차에 대해서 반응 함수를 총 습윤 에너지 단위의 예보 오차로 설정하여 실험을 수행하고 그 결과를 건조 에너지 반응 함수로 계산한 위의 결과와 비교하여, 반응 함수가 결과에 미치는 영 향을 조사하였다. 여름 사례에 대하여는 총 건조 에 너지를 반응 함수로 한 실험과 동일하게 총 관측 효 과에 대해서는 TEMP가, 정규화된 관측 효과에 대해 서는 BOGUS가 예보 오차를 많이 감소시켰다. 반면 ATOVS 자료의 경우 총 건조 에너지 단위의 예보 오 차에는 긍정적인 효과를 보였지만, 총 습윤 에너지 단 위의 예보 오차에 대해서는 부정적인 효과를 나타내 어 반응 함수에 따라 민감하게 반응 하는 것을 확인 할 수 있었다. 이와 같은 결과는 ATOVS의 AMSU-A 센서 관측 자료 (온도)가 총 습윤 에너지 단위 예보 오차에 대해선 부정적인 효과를 보였기 때문으로 보 인다. 선행 연구들에서는 AMSU-A 센서가 예보 오차 를 줄이는데 기여도가 높은 것으로 나타나 이 연구의 결과와 다른데, 그 이유는 선행 연구들이 반응 함수 를 전구로 설정한 반면 이 연구는 반응 함수를 한반 도 부근으로 설정하여 한반도에 영향을 준 특정 시점 의 예보 오차에 대한 AMSU-A의 효과를 봤기 때문 이다. 즉 전구 예보 오차를 감소시키는 데는 AMSU$\mathrm{A}$ 가 효과적이지만 한반도 부근의 특정 사례에 대해 서는 꼭 그렇지는 않으며, 향후 더 다양한 사례에 대 해 한반도 부근으로 반응 함수 지역을 제한하여 관측 자료가 예보에 미치는 영향과 특성을 파악하는 것이 한반도에 발생하는 위험 기상 사례의 예측성 향상에 
필요하다는 것을 의미한다. 겨울 사례의 경우 총 습 윤 에너지 단위 예보 오차로 한 실험의 결과는 전반 적으로 총 건조 에너지 단위 예보 오차로 실험 했을 때와 유사했는데, 이는 총 습윤 에너지 단위 예보 오 차를 계산할 때 얼음에 대한 비습이 계산이 되지 않 기 때문이며, 약간의 차이는 수증기에 대한 비습 때 문인 것으로 분석되었다.

두 사례에 대한 실험을 통하여 한반도에 발생한 위 험 기상 사례의 예보 오차에 대한 관측의 영향은 주 로 한반도의 주변 및 풍상측인 서쪽에 나타나는 것을 확인할 수 있었으며, 예보 시간이 길어질수록 그 분 포가 한반도 주변으로 확대 되는 것을 알 수 있었다. 또한 모든 자료에 포함된 관측 종이 예보에 긍정적인 효과를 주지는 않는다는 것을 알 수 있었고, 관측 종 내에서도 긍정적인 효과를 보이는 관측의 비율은 이 두 사례의 경우 $50 \%$ 를 넘지 않음을 확인할 수 있었 는데, 이는 전구 모델을 이용한 Gelaro et al. (2010) 의 50 54\%, 지역 모델을 이용한 Kunii et al. (2012) 의 $50 \%$ 보다 작은 값이다. 또한 반응 함수의 성질에 따라 관측 종들의 효과가 다르게 나타나는 것을 확인 할 수 있었고, 겨울 사례의 경우 총 습윤 에너지 단 위의 예보 오차 계산에 있어 통합 모델 수반 모델의 특성 상 얼음에 대한 비습이 계산되지 않기에, 대설 사례에 대하여 습윤 에너지 예보 오차를 이용해서 관 측 효과를 계산하는 것은 적절치 않다고 판단된다.

이 연구의 결과와 관련 후속 연구는 한반도에 위험 기상 사례 발생 시 한반도 풍상측 및 주변 지역의 관 측 자료가 예보에 미치는 영향을 상시적으로 감시, 분 석해서 예보에 활용할 수 있는 기반을 마련하는 데 도움이 될 것이다.

\section{감사의 글}

본 연구는 기상청 기상지진기술개발사업 (CATER 2012-2030)의 지원으로 수행되었습니다.

\section{REFERENCES}

Baker, N. and R. Daley, 2000: Observation and background adjoint sensitivity in the adaptive observation-targeting problem. Quart. J. Roy. Meteor. Soc., 126, 1431-1454.

Bouttier, F. and G. Kelly, 2001: Observing-system experiments in the ECMWF 4D-Var data assimilation system. $Q . J$. R. Meteorol. Soc., 127, 1469-1488.

Buizza, R., 1994: Localization of optimal perturbations using a projection operator. Quart. J. Roy. Meteor. Soc., 120, 1647-1681.

Cardinali, C., 2009: Monitoring the observation impact on the short-range forecast. Quart. J. Roy. Meteor. Soc., 135, 239-250.

Clayton, A. M., 2004: VAR Scientific Documentation 60, UK Met. Office., 1-12.

Edwards, J. M. and A. Slingo, 1996: Studies with a flexible new radiation code. 1: Choosing a configuration for a large scale model. Quart. J. Roy. Meteor. Soc., 122, 689-719.

English, S., R. Saunders, B. Candy, M. Forsythe, and A. Collard, 2004. 'Met Office satellite data OSEs.' Pp. 146-156 in Proc. Third WMO workshop on the impact of various observing systems on numerical weather prediction, Alpbach, Austria. WMO/TD-1228, Geneva.

Errico, R. M., 1997: What is an adjoint model? Bull. Amer. Meteor. Soc., 78, 2577-2591.

Essery, R., M. Best, and P. Cox, 2001: MOSES 2.2 technical documentation. Hadley Centre technical note 30.

Gelaro, R., Rolf H. Langland, Simon Pellerin, Ricardo Todling, 2010: The THORPEX Observation Impact Intercomparison Experiment. Mon. Wea. Rev., 138, 4009-4025.

, and Y. Zhu, 2009: Examination of observation impacts derived from observing system experiments (OSEs) and adjoint models. Tellus, 61A, 179-193.

Gregory, D., R., Kershaw, and P. M. Inness, 1997: Parameterization of Momentum Transport by Convection 2: Test in single-Column and General Circulation Models. Quart. J. Roy. Meteor. Soc., 123, 1153-1184.

Joo, S., A. C. Lorenc, and R. Marriott, 2012: The impact of Metop and other satellite data within the Met Office global NWP system using an adjoint-based sensitivity method, Forecasting Research Tech. Rep. 562, Met Office, Bracknell, United Kingdom.

Jung, B.-J. and H. M. Kim, 2009: Moist-adjoint based forecast sensitivities for a heavy snowfall event over the Korean peninsula on 4-5 March 2004. J. Geophys. Res., 114, D15104.

, F. Zhang, and C.-C. Wu, 2012: Effect of targeted dropsonde observations and best track data on the track forecasts of Typhoon Sinlaku (2008) using an Ensemble Kalman Filter. Tellus A, 64, 14984.

Kelly, G., J.-N. Thépaut, R. Buizza, and C. Cardinali, 2007: The value of observations. I: Data denial experiments for the Atlantic and Pacific. Quart. J. Roy. Meteor. Soc., 133, 1803-1815. 
Kershaw, R. and D. Gregory, 1997: Parameterization of Momentum Transport by Convection 1: Theory and Cloud Modeling Results. Quart. J. Roy. Meteor. Soc., 123, 1133-1151.

Kim, H. M., J. K. Kay, and B.-J. Jung, 2008: Application of adjoint-based forecast sensitivities to Asian dust transport events in Korea. Water, Air, and Soil Pollution, 195, 335-343.

Kim, S.-M., H. M. Kim, S.-W. Joo, H.-C. Shin, and D. Won, 2011: Development of tools for calculating forecast sensitivities to the initial condition in the Korea Meteorological Administration (KMA) Unified Model (UM). Atmosphere, 21(2), 163-172. (in Korean with English abstract)

Kunii, M., T. Miyoshi, and E. Kalnay, 2012: Estimating impact of real observations in regional numerical weather prediction using an ensemble Kalman filter. Mon. Wea. Rev., 140, 1975-1987.

Langland, R. H. and N. L. Baker, 2004: Estimation of observation impact using the NRL atmospheric variational data assimilation adjoint system. Tellus, 56A, 189-201.
Lock, A. R., A. R. Brown, M. R. Bush, G. M. Martin, and R. N. B. Smith, 2000: A new boundary-layer mixing scheme. Part 1: Scheme description and single-column model tests. Mon. Wea. Rev., 128, 3187-3199.

Lord, S., Zapotocny, T., and Jung, J., 2004: 'Observing system experiments with NCEP's global forecast system.' pp. 56-62 in Third WMO workshop on the impact of various observing systems on numerical weather prediction, Alpbach, Austria, WMO/TD-1228, Geneva.

Webster, S., A. Brown, A. R., Cameron, D. R., and C. P. Jones, 2003: Improvements to the representation of orography in the Met Office Unified Model. Quart. J. Roy. Meteor. Soc., 129, 1989-2010.

Wilson, D. R. and S. P. Ballard, 1999: A microphysically based precipitation scheme for the UK Meteorological Office unified model. Quart. J. Roy. Meteor. Soc., 125, 1607-1636.

Zhu, Y. and R. Gelaro, 2008: Observation sensitivity calculations using the adjoint of the Gridpoint Statistical Interpolation (GSI) analysis system. Mon. Wea. Rev., 136, 335-351. 